\title{
PSEUDOMUlLERIa DALYI (ACOSTAEA DALYI), A RARE CEMENTED BIVALVE OF WESTERN GHATS
}

\author{
N.A. Madhyastha \\ Malacology Centre, Poornaprajna College, Udupi, Karnataka 576101, \\ India.
}

Of the six families of Unionoids, the family Etheridae is unique in showing discontinuous distribution (Smith, 1898; Rao, 1988; Bogan \& Hoeh, 2000). Most malacologists recognise three genera in Etheridae, viz., Acostaea (South America), Pseudomulleria (India) and Etheria (Africa). The Indian genus is often identified as Acostaea under a distinct subgenus, Pseudomulleria (Rao, 1988), however these days the Indian Etherid is identified as Pseudomulleria (Cummings, 2000; Bogan \& Hoeh, 2000) and not Acostaea! Thus, Pseudomulleria dalyi is the only freshwater cemented bivalve of Western Ghats and is found in some restricted localities (Madhyastha, 1997). No extensive survey has been made so far to assess the abundance of this rare Gondwanaland relict.

During my survey of freshwater molluscs in Western Ghats under the Western Ghats Biodiversity Network of Centre for Ecological Studies, Indian Institute of Science, Banglore, I was able to locate two places, both in Karnataka, where the Pseudomulleria are found in small populations. The first being the type locality (?) in Bhadra River $\left(13^{0} 3^{\prime} \mathrm{N}, 75^{\circ} \mathrm{E}\right)$ and the other, $50 \mathrm{~km}$ north of Bhadra, in Tunga River $\left(13^{0} 5^{\prime} \mathrm{N}, 75^{\circ} \mathrm{E}\right)$. Although there is a report of its occurrence in Koyna, no detailed information is available as to its exact locality and distribution. My attempt to locate the Pseudomulleria in Koyna has been futile.

The population in Bhadra River: The Pseudomulleria are firmly cemented to rocks with their right valve underwater, often in clusters of 5-10 in Bhadra River, near Kalasa of Chickmagalur District. There are about 300-400 of them in one locality. During late summer they are visible in transparent water, just below the water level on the slopes of the rocks. The colour of the shells blends perfectly with the rock in which they grow and the silt covering both the rock and the shells further increase their camouflage. Hence, only a trained eye can locate the bivalve in the water. These bivalves live in inaccessible locality and hence they have been safe until now. Incidentally, a project called Upper Bhadra Project is contemplated down stream of Bhadra by the Government of Karnataka, where the Pseudomulleria inhabit. Population in Tunga River: The other locality is in Tunga River, in Kasaravalli, about 50km North of Kalasa, in Thirthahalli Taluk. A few specimens in this locality had a peg-like projection on the right valve and were loosly attached to rocks. Its (peg-like projection) significance is yet to be established. The river in the area is being used for various purposes including bathing, washing and agriculture. Dynamite and chemicals are used to catch fish. Still there is small population of about 100 individuals of Pseudomulleria existing in the area.

The uniqueness: The Pseudomulleria is a Gondwanaland relict, has survived for over 80 million years and has seen the emergence of the Western Ghats. It is an example of discontinuous distribution and is an example of a living fossil.

The relationship among various species of Etheridae has been uncertain until date. Ever since the species was described, it was included in Etheridae along with Acostaea and Etheria (Smith, 1898; Rao, 1989; Cummings, 2000). However, recent mitochondrial DNA analysis by Bogen and Hoeh (2000) have shown that the Pseudomulleria is quite distinct from the other two cemented bivalves found in Africa and South America. Pseudomulleria is undoubtedly one of the most unique and rare bivalves of Western Ghats.

Threats: The Upper Bhadra Project, which is on the anvil, is perhaps the biggest threat to Pseudomulleria in its type locality near Kalasa of Chickmagalur. The area when completely submerged due to the dam, the pressure from the high column of water and possible siltation, would certainly wipe out this rare species. The population near Kasarvalli of Shimoga District has a different problem. Being under intense anthropogenic pressure and overexploitation of fish of the area, the population is under grave threat. The Glocidia (the larvae) of Unionids live as parasites in the gills of fish and hence the loss of fish community, needless to say, is of concern to Pseudomulleria. We are yet to study the larval forms and life history of this species to estimate the loss. Nevertheless, this species should be accorded a very high priority for conservation.

\section{Acknowledgements}

I am grateful to Prof. Madhav Gadgil for his kind encouragement and support.

\section{References}

Cummings, S.K. (2000). Freshwater Mussel (Unionoida) Genera of the World, (Internet) Illinois. Natural History Survey Centre for Biodiversity, Mollusks Illinois.

Bogan, E.A. and W.R. Hoeh (2000). On becoming cemented: evolutionary relationships among the genera in the freshwater bivalve family Etheridae. In: Haroerm E.M., J.D. Taylor. and J.A. Nrame, Editors. The Evolutionary Biology of the Bivalvia. Geological Society, London, Special publication 177: 159-168.

Naggs, F. (1997). Mollusca Specialists Report. IUCN 1-25.

Rao, N.V.S. (1988). Handbook - Freshwater Molluscs in India, ZSI Calcutta.

Smith, A. (1898). Description of Mulleria dayli n. sp. From India. Proceedings of the Malacological Society London. 3: 14-16. 